Acta Technologica Agriculturae 1

Nitra, Slovaca Universitas Agriculturae Nitriae, 2021, pp. 41-47

\title{
FORMATION OF CROP YIELDS OF ENERGY CROPS DEPENDING ON THE SOIL AND WEATHER CONDITIONS
}

\author{
Maroš KORENKO*, Volodymyr BULGAKOV², Vasyl KURYLO³, Maksym KULYK ${ }^{4}$, \\ Alexander KAINICHANKO ${ }^{4}$, Yevhen IHNATIEV ${ }^{5}$, Eva MATUŠEKOVÁ ${ }^{1}$ \\ ${ }^{1}$ Slovak University of Agriculture in Nitra, Slovakia \\ ${ }^{2}$ National University of Life and Environmental Sciences of Ukraine \\ ${ }^{3}$ Vinnytsia National Agrarian University, Vinnytsia, Ukraine \\ ${ }^{4}$ Poltava State Agrarian Academy, Poltava, Ukraine \\ ${ }^{5}$ Tavria State Agrotechnological University, Ukraine
}

\begin{abstract}
The article presented discusses the need to use plant biomass made of energy crops grown in marginal soils as an alternative energy source. Variability of biometric indicators of the plant vegetative parts (productivity elements) was experimentally established: stem quantity per area unit and stem height depending on the soil and weather conditions. Based on the five-year research, there was observed a significant influence of soil and climatic growing conditions (average daily air temperature; rainfall; soil fertility) on formation of crop energy productivity. Results showed that the variability of stem density and height; dry phytomass productivity of millet switchgrass and giant miscanthus during observed years depended on the studied factors. Correlation-regression analysis proved and characterized the influence of soil and climatic conditions during the growing season of energy crops on the yield of dry phytomass of millet switchgrass and giant miscanthus in the central part of the Ukraine forest-steppe. The impact proportion share of weather conditions and plant productivity elements on the level of energy crops yields was calculated.
\end{abstract}

Keywords: millet switchgrass; giant miscanthus; biometric indicators of plants; phytomass productivity

Currently, there is a tendency for the gradual depletion of non-renewable energy resources (oil, gas, coal) all over the world. As Tian et al. (2017) pointed out, nowadays, world energy demand is covered using oil (35\%), coal (23\%), natural gas (21\%) and by nuclear fuel (7\%). All these resources are non-renewable. Given the significant projected increase in energy demand, experts estimate that coal reserves will last for 250-300 years, natural gas reserves for $50-70$ years, and oil reserves for $30-40$ years, which is why the world scientific community puts so much emphasis on alternative energy sources, especially on potential of plants (Mehmooda et al, 2017). At the same time, there is a significant number of biomass energy sources for biofuel production in Ukraine: crop residues, waste from wood industry, and energy crops (Kurylo et al., 2013). The last type is represented mainly by perennial plants, which are acclimated to the growing conditions and it is possible to produce a high yield of phytomass by their cultivation in low-yielding soils. Among them, the following crops are distinguished: perennial sorghum, miscanthus (ivory), switchggrass (millet rod), willow, etc. Energy crops are herbs, shrubs, fast-growing trees, or other plants, the phytomass of which can be used as biofuel feedstock. The most common are miscanthus, millet (switchgrass) and willow (Costanza et al., 2017). Millet switchgrass belongs to the family of cereals (Gramineae); it has hollow stems of different colours reaching up to 3 meters in height, forms an inflorescence - paniculate - that can have $15-50 \mathrm{~cm}$ length, and reproduces by seeds and rhizome division. Miscanthus belongs to the cereal family (Gramineae); the most frequent species are Miscanthus giganteus, Miscanthus sinensis, and Miscanthus sacchariflorus.

Plants of the Miscanthus giganteus species (giant miscanthus) are very tall - up to 5 meters - they form a powerful phytomass, with an average winter hardiness and drought resistance. Giant miscanthus was an allotriploid derived from Miscanthus sinensis and Miscanthus saccharifolius and its mother form was Miscanthus saccharifolius (Chramiec-Głąbik et al., 2012). It reproduces only vegetatively and is the most common species in Ukraine (Kulyk et al., 2019). Samson et al. (2005); Christian and Elbersen (1998) identified the benefits of using biomass made of millet switchgrass and miscanthus in energy and fibre production: high clean energy production per hectare; low costs; low plant nutrient requirements; low ash content in raw materials, high moisture utilization; wide spread; easy cultivation, easy adaptation to growing conditions for cultivation in low-yielding soils, and ability to store carbon in the soil. They recommend growing energy crops in lowproductive soils and degraded lands (Matías et al., 2019), which can be considered marginal soils - these are soils, at which the agricultural production is economically inefficient due to the low soil fertility and environmental restrictions that result from soil degradation, hydrophobicity, etc. 
Furthermore, multiple scientists (Tang et al., 2010; Thakrar et al., 2018) associate the term "marginal soils" with the trends of land utilization, and later - with soil quality. Thakrar et al. (2018) has determined the level of soil organic carbon and its amount obtained from plant material. Their research in the US and India showed that the conversion of crop residues to organic carbon and $\mathrm{CO}_{2}$ is more of a conservation process occurring around the world. Mathematical calculations determined that the carbon intensity and the amount of $\mathrm{CO}_{2}$ from plant residues per unit of energy in biofuels does not depend on the amount of residue removed and the location of the raw materials (Macák et al., 2015). According to Thakrar et al. (2018), the economic impact of the use of bio resources is partially dependent on the ability of the management to strategically identify land for the transition from current use to obtaining of raw materials for bio resource production.

Along with the findings of Baxter et al. (2014) regarding the use of agricultural biomass for energy purposes, Tang et al. (2010) analysed the current status and future potential of China's marginal land resources, energy savings and energy reductions of harmful emissions. At the same time, the findings indicate that the country has enormous energy potential in terms of marginal land resources. Kulyk (2019) observed changes in soil at multiyear plantations of energy crops: the soil level in the layer $0-30 \mathrm{~cm}$ decreases, the content of available phosphorus in soil increases by $8-13 \%$, changes in calcium and magnesium are minor (except for miscanthus plantations in which the first indicator decreased), changes in total nitrogen content are relatively large (4\% more than in control samples).

Simultaneously, Čedík et al. (2018) pointed out the need to study environmental factors of the most common alternative fuel production - biodiesel biofuels made of bio-raw materials.

Given the significance of the aforementioned, this paper pays attention to:

- determination of variability of the plant productivity elements of millet switchgrass and giant miscanthus depending on the growing conditions;

- determination of relationship between the plant biometrics and yield of dry phytomass of these energy crops;

- determination of influence of the soil and weather conditions on the yield of conditionally wet and dry phytomass of millet switchgrass and giant miscanthus.

\section{Material and methods}

Experimental work was carried out at Poltava State Agrarian Academy on the basis of scientific international project "P4R" (2010-2013) established between the Netherlands and Ukraine, state research topic "Agro-ecological principles of cultivation of energy crops in Ukraine" (2014-2017), and the applied research scientific project of the Ministry of Education and Science of Ukraine "Development of optimal energy systems taking into account the existing potential of renewable energy sources in the conditions of the foreststeppe of Ukraine" (2017-2019). Experiment with energy crops (millet switchgrass and giant miscanthus) took place in the central part of the forest-steppe of Ukraine at the state agricultural enterprise "Jubilee" in Poltava district, village Brychkivka. Annual precipitation in this area is $450-550 \mathrm{~mm}$; irrigation rate ranges from 1.9 to 1.3 . Crops were planted in the experimental plot in 2010, and experimental studies were conducted during the period since 2012 to 2016 . The experiment observed the cultivation of energy crops (millet switchgrass and giant miscanthus):

- option 1 - high-yielding soils - FS (humus content over $1.5 \%)$

- option 2 - marginal lands soils - MF (humus content less than $1.5 \%)$.

In terms of climate and soil, the conditions were typical for this region and all technological operations were carried out simultaneously in both plots with energy crops: soil cultivation (autumn and spring); sowing of millet switchgrass seeds and planting giant miscanthus with the weeding in the optimal time, as weeds appear in the first and beginning of the second year of a plant vegetation. Further soil cultivation was not carried out, since the energy crops shaded row spacing with their phytomass, thus suppressing the weeds.

Over the research years, the energy crops were subjected to conventional (Dospehov, 1985), as well as special research methods (Kurylo et al., 2013). Each year since 2012 to 2016, the experiments were repeated four times, the options were placed randomly, the total plot area for each crop was $60 \mathrm{~m}^{2}$, and the area of the reference plot was $50 \mathrm{~m}^{2}$.

In order to ensure the experiment reliability, the numbers of stems and plant heights of millet switchgrass and giant miscanthus plants were determined as the arithmetic average of 50 plants of each crop from the selected sheaf samples for each variant and this process was repeated four times in each year.

In order to prevent errors during the experiment, the productivity and yield of phytomass of energy crops were determined from the sheaf samples, which were diagonally sampled four times and weighed. Subsequently, the selected average sample was dried, and the dry weight mass was calculated taking into account the moisture content of the raw material at the end of the growing season (Ben Fradj et al., 2020; Kulyk et al., 2019).

The obtained research results were processed by means of analysis of variance in Statistaca 6.0.

The theoretical value of the Fisher test $(F)$ was found based on the degrees of freedom for the variance of options and degrees for error. If the actual Fisher criterion is more than theoretical $\left(F_{a}>F_{05}\right)$, then there are significant variations in the experiment and the null hypothesis is rejected.

On order to determine the significant differences, the following was calculated:

1. experiment error $\left(S_{x}\right)$ and the difference of the standard deviation $\left(S_{d}\right)$ :

$$
S_{x}=\sqrt{\frac{s^{2}}{n}}, S_{d}=\sqrt{\frac{2 s^{2}}{n}}
$$

where:

$s^{2}$ - dispersion

$n$ - number of repetitions 
2. the least significant difference for the $5 \%$ significance level $\left(H I P_{05}\right)$ in absolute and relative terms:

$$
\begin{array}{r}
H O P_{05}=t_{05} S_{d} \\
H I P_{05}=\frac{t_{05} S_{d}}{\bar{x}} 100
\end{array}
$$

where:

$t_{05}-$ tabular values of the criterion $t$ for a $5 \%$ significance level

$\bar{x}$

- arithmetic mean value

The coefficient of variation was determined as the ratio of the standard deviation $(S)$ to the average level $(x)$ :

$$
V=\frac{s}{\bar{x}} 100
$$

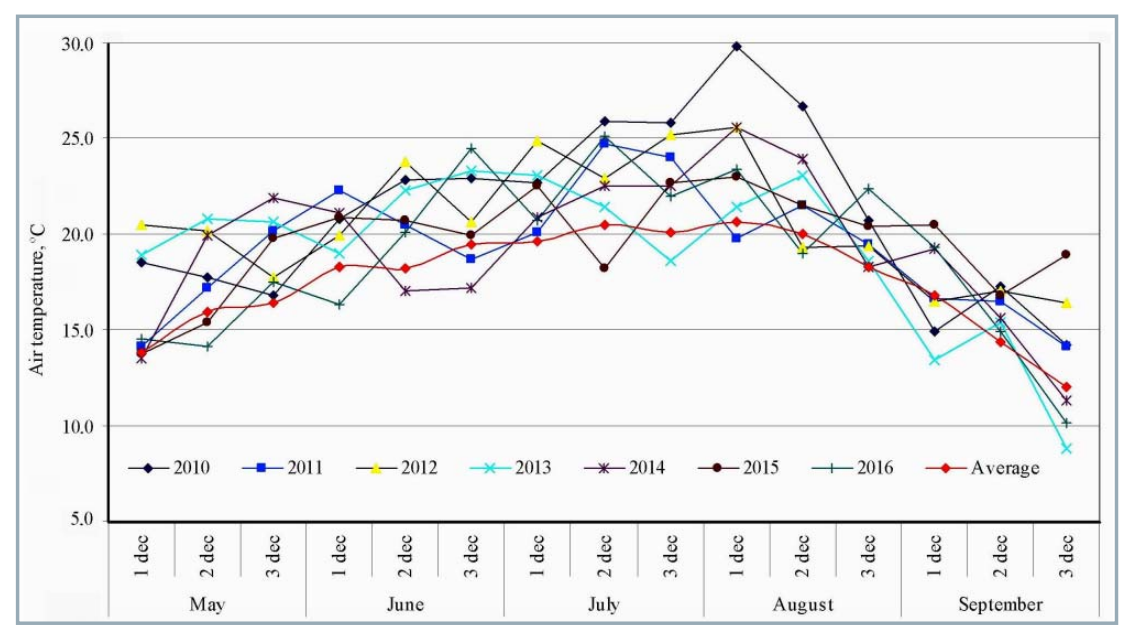

Fig. 1 Average decade air temperature in comparison to long-term average data (average b/d) during the vegetation of energy crops (2010-2016)

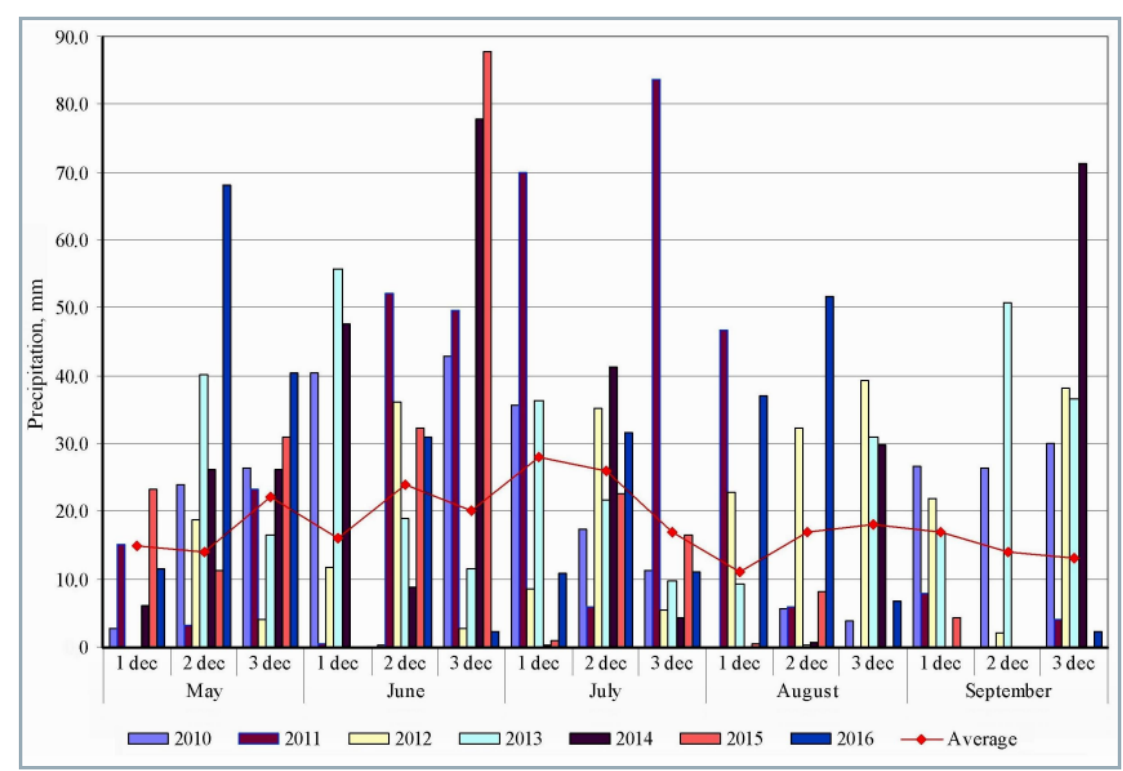

Fig. 2 Average decade rainfall in comparison to the long-term average data (average b/d) during the vegetation of energy crops (2010-2016)
To estimate the reliability of the correlation coefficient, its error ( $s r)$ and materiality criteria $\left(t_{r}\right)$ were calculated as follows:

$$
s r=\sqrt{\frac{1-r^{2}}{n-2}}, \quad t_{r}=\frac{r}{s_{r}}
$$

where:

$r \quad$ - correlation coefficient

If $t_{r}>t_{\text {theor }}$ (theoretical value of the criterion), then correlation is significant and vice versa. It was accepted that if $r<0.3$, the correlation is weak; if $r=$ $0.3-0.7$, the correlation is average, and if $r>0.7$, then the correlation is strong.

\section{Results and discussion}

Weather conditions during the vegetative period of energy crops since the third to seventh year (2010-2016) were dynamically changing and showed values of temperature and rainfall that differed from the average long-term data (Figs. 1-2).

The aboveground vegetative mass of millet switchgrass and giant miscanthus for biofuel purposes was harvested after the third year of vegetation - this is due to rooting, growth rate and plant development, which determines the yield potential (Fig. 3). For this very reason, the study results for energy crops are presented since 2012.

Under the conditions of the central forest-steppe, the number of plant stems of millet switchgrass varied from 24.0 to 70.1 pcs. when cultivated in high-productive soils (the coefficient of variation $V$ was $42.1 \%$ ); the number of plant stems of giant miscanthus varied from 12.1 to 23.4 pcs. $(V=39.3 \%)$. Considering the marginal soils, this indicator varied from 21.3 to 34.1 pcs. with a coefficient of variation $V=17.8 \%$ for millet switchgrass and from 11.4 to 21.3 pcs. with a coefficient of variation $V=25.8 \%$ for giant miscanthus. When cultivated in high-productive soils, the height of millet switchgrass plants since the third to seventh year of vegetation varied from 110.3 to $172.1 \mathrm{~cm}(V=34.7 \%)$; in marginal soils, this indicator varied from 112.4 to $179.3 \mathrm{~cm}(V=15.4 \%)$.

Considering the giant miscanthus, there was observed a tendency to increase the plant height (since the 


\begin{tabular}{|c|c|c|c|c|c|c|c|c|c|c|c|c|c|c|c|c|}
\hline \multirow[b]{2}{*}{ Cultures } & \multicolumn{4}{|c|}{2010 year } & \multicolumn{4}{|c|}{2011 year } & \multicolumn{4}{|c|}{2012 year } & \multicolumn{4}{|c|}{2013 year } \\
\hline & $\mathrm{s}^{*}$ & su & $\mathrm{a}$ & $\mathrm{w}$ & $\mathrm{s}$ & su & $\mathrm{a}$ & $\mathrm{w}$ & $\mathrm{s}$ & su & $\mathrm{a}$ & $\mathrm{w}$ & $\mathrm{s}$ & su & $\mathrm{a}$ & $\mathrm{w}$ \\
\hline \multicolumn{17}{|l|}{ Millet switchgrass } \\
\hline \multirow{2}{*}{\multicolumn{17}{|c|}{\begin{tabular}{c|c} 
Giant miscanthus & \\
Marking:
\end{tabular}}} \\
\hline & & & & & & & & & & & & & & & & \\
\hline \multicolumn{17}{|c|}{ sowing / planting } \\
\hline \multirow{2}{*}{\multicolumn{17}{|c|}{\begin{tabular}{l|l}
2016 year \\
su
\end{tabular}}} \\
\hline & $\mathrm{s}$ & su & $\mathrm{a}$ & $\mathrm{w}$ & $\mathrm{s}$ & su & $\mathrm{a}$ & $\mathrm{w}$ & $\mathrm{s}$ & su & $\mathrm{a}$ & $\mathrm{w}$ & $\mathrm{s}$ & su & $\mathrm{a}$ & $\mathrm{w}$ \\
\hline \multicolumn{17}{|l|}{ Millet switchgrass } \\
\hline \multirow{2}{*}{\multicolumn{17}{|c|}{ Giant miscanthus }} \\
\hline & & & & & & & & & & & & & & & & \\
\hline & & & estin & & & & & & & & & & & & & \\
\hline
\end{tabular}

Fig. 3 Logistic chain of cultivation, plant care and harvesting of energy crops, 2010-2017

$\mathrm{s}$ - spring period, su - summer period, a - autumn period, $\mathrm{w}$ - winter period

third to seventh year of vegetation) in high-productive soils - from 172.1 to $345.8 \mathrm{~cm}(V=41.2 \%)$; the number of plant stems varied from 15.3 to 202.3 pcs. ( $V=64.7 \%)$. In marginal soils, the plant height varied from 162.2 to $325.5 \mathrm{~cm}(V=24.4 \%)$ and the number of plant stems varied from 12.1 to 23.4 pcs. $(V=26.8 \%)$.

The greatest increase in plant height for millet switchgrass was observed during the spring and summer, and in the spring for giant miscanthus, with an increase in growth rates in the spring and summer and a gradual decrease in July-August. This is primarily due to the amount of precipitation during this period and is confirmed by the conclusions of previous studies (Kulyk et al., 2019) and the results of other authors (Wang et al., 2015), who conducted similar research.

Along with the results of previous studies regarding the characteristics of the formation of energy crop yields (Kulyk et al, 2019), Kurylo et al. (2013),

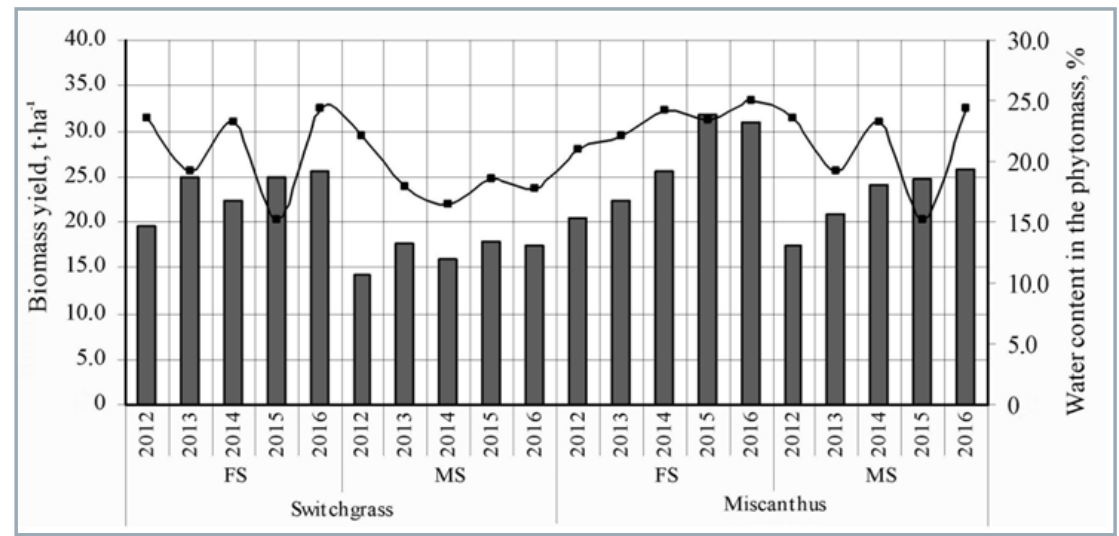

Fig. 4 Productivity and moisture content in the phytomass of energy crops during the period of 2012-2016

$H I P_{05}$ (cultures) $=2.71 ; H I P_{05}$ (soils) $=5.04 ; H I P_{05}$ (years) $=1.68 ; \mathrm{FS}-$ highly-productive soils; MS - marginal soils was also confirmed by previous study (Kulyk et al., 2019).

It was determined that during the cultivation of millet switchgrass, the phytomass moisture content varied from 23.1 to $25.0 \%$ in high-productive soils, and from 20.0 to $25.2 \%$ in marginal soils. The higher yield of dry phytomass was recorded with the cultivation of millet switchgrass in high-productive soils during the period since the third to seventh year of vegetation (14.7-19.3 t.ha ${ }^{-1}$; Fig. 4).

The moisture content in giant miscanthus phytomass was slightly different compared to millet switchgrass, and the productivity of the stem and plants increased since the third to seventh year of the vegetation under different growing conditions. Its moisture content varied from 24.2 to $33.1 \%$ when cultivated in high-productive soils, and from 29.1 to $33.0 \%$ when cultivated in marginal soils and depended on the weather conditions. The highest yield of dry miscanthus phytomass was shown by samples cultivated in high-productive soils during the fourth and sixth year of vegetation (16.7-23.9 t.ha-1).

According to the results of the correlation and regression analysis at a $5 \%$ level of significance, it was determined that the number of stems of one plant has the greatest influence on the productivity of dry phytomass of millet switchgrass and giant miscanthus (Figs. 5-8).

The established regression dependence indicates that the increase in yield of dry phytomass of millet switchgrass under the Central Forest Steppe conditions is more determined by the number of stems per unit area ( $R=0.78)$ than the height of plants $(R=0.39)$.

In terms of giant miscanthus, the following dependence was established: with an increase in its stem density $(R=0.85)$ and height $(R=0.75)$, the dry phytomass yield will increase and vice versa.

Weather conditions (average daily air temperature and precipitation amount during the growing season May-September) also significantly contribute to the formation of the phytomass yield of energy crops taken for the study (Table 1).

The yield of energy crops in marginal soils showed a strong inverse 


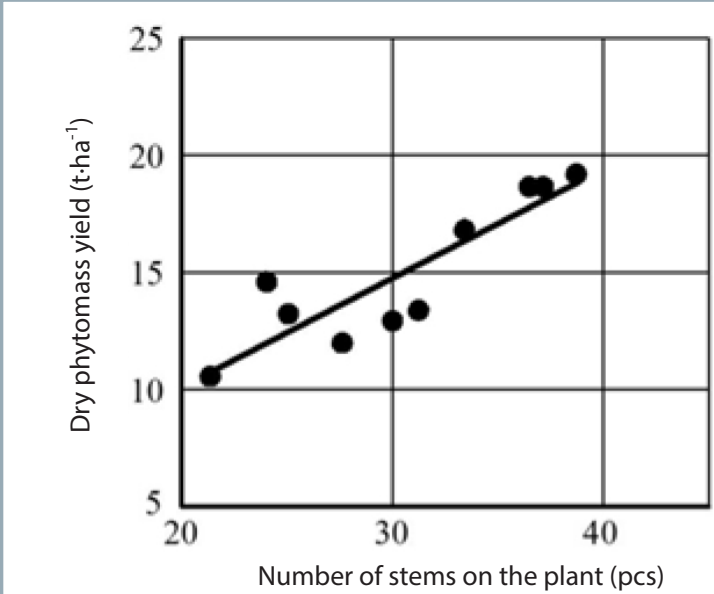

Fig. 5 Relationship between stem density and phytomass yield of millet switchgrass (2012-2016)

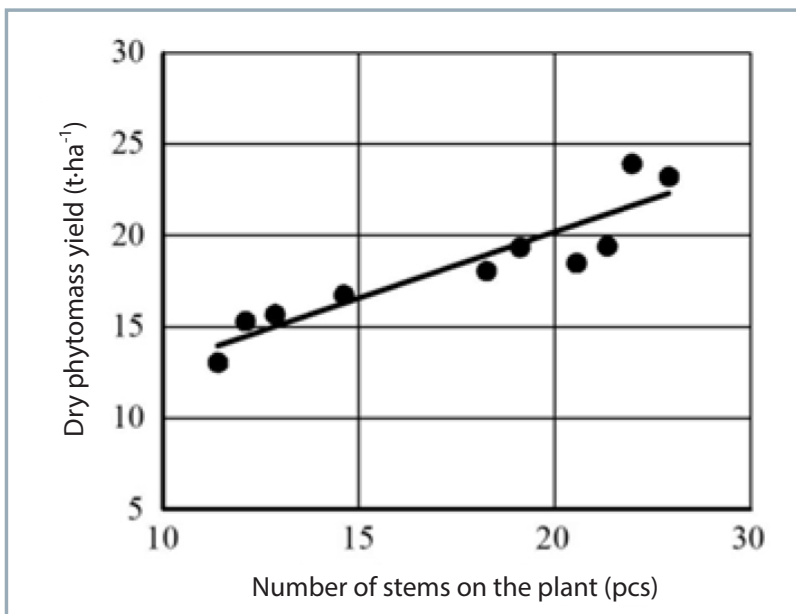

Fig. 6 Relationship between stem density and yield of giant miscanthus phytomass (2012-2016)

relationship with the average daily air temperature, which indicates that the increase in one indicator will decrease the other and vice versa. To a moderate degree, the yield of giant miscanthus was influenced by the volume of precipitation during plant vegetation in high-productive soils; when grown in marginal soils, this relationship disappeared.

Determining the degree of influence of studied factors on dry phytomass yield of energy crops made it possible

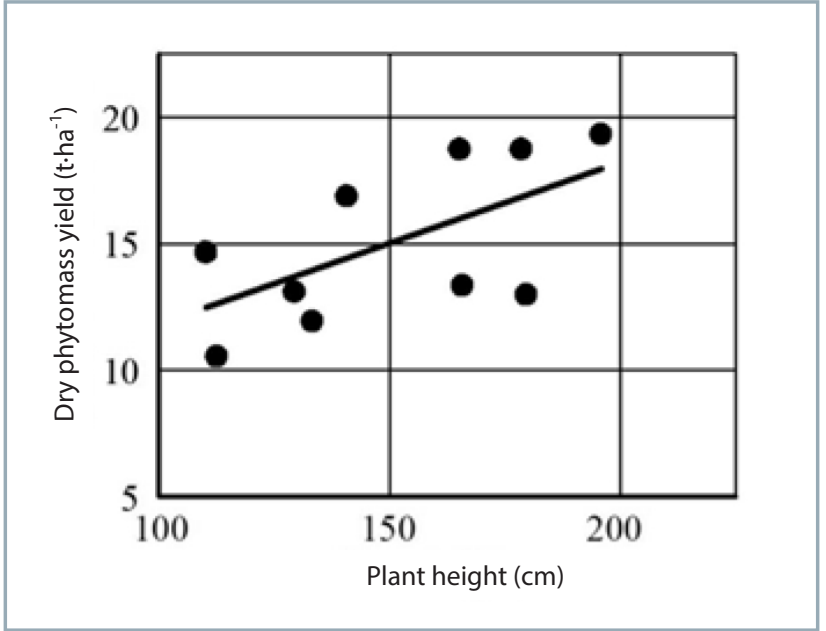

Fig. 7 Relationship between plant height and phytomass yield of millet switchgrass (2012-2016)

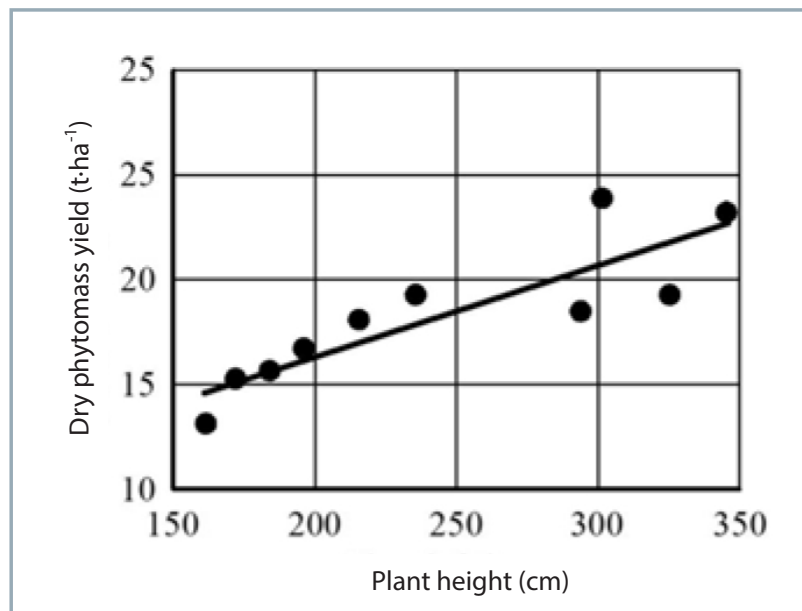

Fig. 8 Relationship between plant height and phytomass yield of giant miscanthus (2012-2016)

to single out the most significant among them (them (Figs. $9 a$ and $9 b)$.

Considering the long-term cultivation of millet switchgrass in high-productive soils and marginal soils, their yield was determined by the number of stems per unit area (38.3 and $35.0 \%$, respectively), the average daily air temperature during the growing season (31.2 and 30.3\%) and the dry content substances in phytomass (15.3 and $15.0 \%)$; the productivity was affected to a lesser extent by

Table 1 Coefficients of linear correlation between weather conditions and dry phytomass yield of energy crops (Pearson), 2012-2016

\begin{tabular}{|l||c|c|c|c|c|}
\hline \multirow{2}{*}{ Crops } & Conditions & $\begin{array}{c}\text { The average daily air } \\
\text { temperature }\left({ }^{\circ} \mathbf{C}\right)\end{array}$ & $\begin{array}{c}\text { Correlation } \\
\text { relationship }\end{array}$ & $\begin{array}{c}\text { Precipitation } \\
(\mathbf{m m})\end{array}$ & $\begin{array}{c}\text { Correlation } \\
\text { relationship }\end{array}$ \\
\hline \hline \multirow{2}{*}{ Millet switchgrass } & high-productive soils & $-0.87^{*}$ & strong & 0.08 & weak \\
\cline { 2 - 6 } & marginal soils & $-0.79^{*}$ & strong & 0.03 & weak \\
\hline \multirow{2}{*}{ Giant miscanthus } & high-productive soils & $-0.54^{*}$ & average & $0.46^{*}$ & average \\
\cline { 2 - 6 } & marginal soils & $-0.77^{*}$ & strong & -0.07 & weak \\
\hline
\end{tabular}

${ }^{*}$ Note: relationships are significant at $5 \%$ significance level 


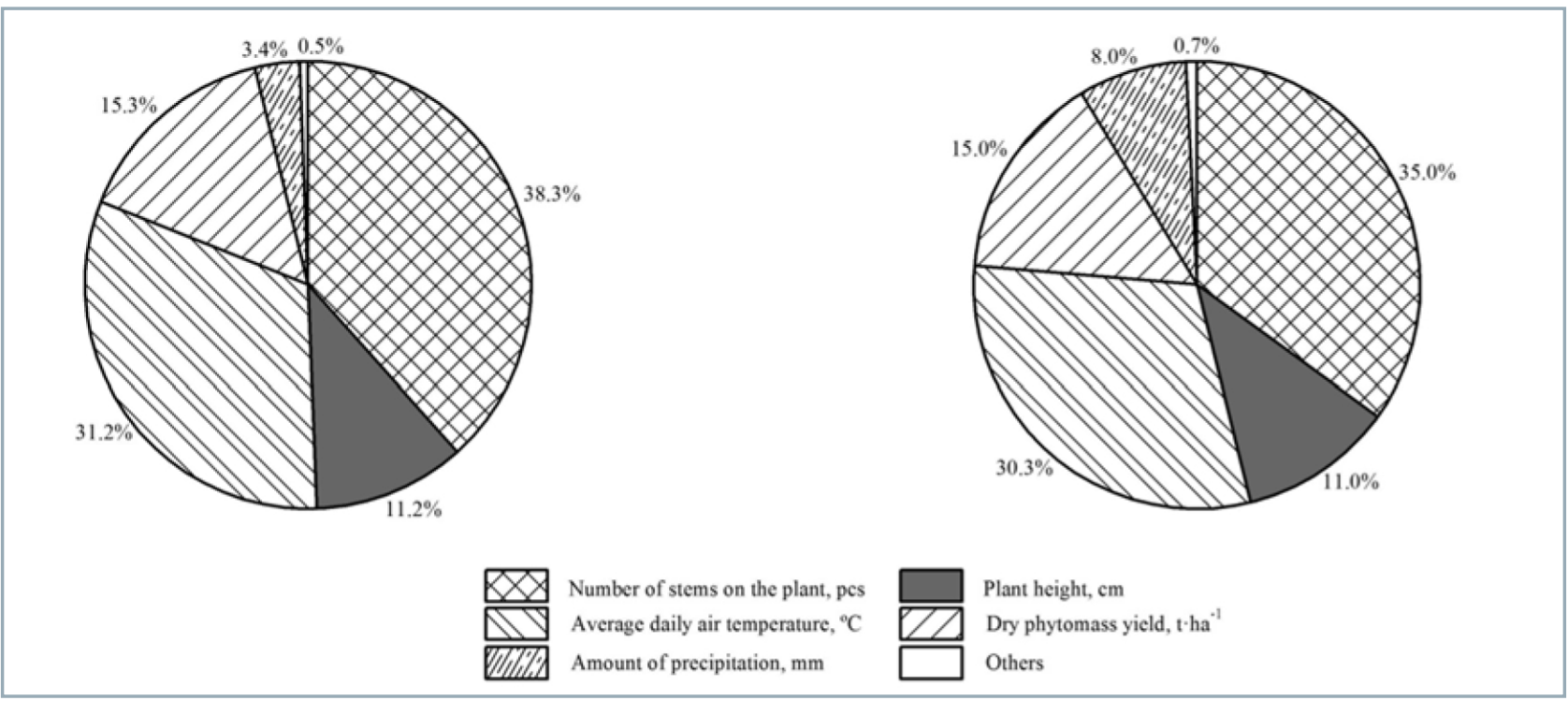

Fig. 9 Effect of plant quantitative indicators and weather conditions on the dry phytomass yield of millet switchgrass in 20122016 when cultivated in a) high-productive soils; b) marginal soils

plant height (11.2 and $11.0 \%)$, the precipitation amount during the growing season (3.4 and $8.0 \%$ ), rest of the factors showed effect less than $0.7 \%$.

The phytomass yield of giant miscanthus over the research years in high-productivity soils and marginal soils was produced thanks to the height of plants $(23.9 \%$ and $25.6 \%$, respectively), the number of stems per unit area ( $20.9 \%$ and $28.8 \%$, respectively), average daily temperature during the growing season $(16.9 \%$ and $22.5 \%)$, dry matter content in the phytomass $(14.0 \%$ and $14.1 \%)$, and the amount of precipitation during the growing season $(23.3 \%$ and $7.9 \%$ ), other factors showed significance less than $0.8 \%$.

\section{Conclusion}

It has been determined that at present, cultivation possibility of multiyear energy crops (millet switchgrass and giant miscanthus) in marginal soils as a raw material for the purposes of biofuel production in both Ukraine and abroad was investigated. In the long-term run, this should reduce energy dependence of Ukraine on imported energy sources by utilization of renewable energy sources.

Over the years of research, there was observed a significant variation in the biometric characteristics of energy crops when cultivated in high-productive soils and marginal soils; differences in productivity indicators were of average values. Millet switchgrass showed the largest increase in the productivity indicators: the highest stem density and plant height occurred from the fourth to sixth vegetation year. Considering the giant miscanthus plants, these indicators increased since the third to seventh vegetation year. Another trend was observed in the cultivation of these crops in marginal soils - there was a clear trend towards an increase in biometric indicators starting since the third to seventh vegetation year.

An increase in plant biometric parameters at the end of the vegetation season, especially the plant height in more fertile soils, is more characteristic for giant miscanthus than for millet switchgrass. Millet switchgrass showed an increase in plant density during cultivation in more fertile soils (with humus content greater than $1.5 \%$ ) in contrast to less fertile marginal soils (with humus content less than 1.5\%), in which the increase in plant height was recorded at the cost of stem density reduction.

In marginal soils, millet switchgrass showed a trend towards an increase in the yield since the third to seventh vegetation year ranging from 10.6 to $13.0 \mathrm{t}^{\mathrm{h}} \mathrm{ha}^{-1}$; giant miscanthus showed yield increase from 13.1 to $19.3 \mathrm{t} \cdot \mathrm{ha}^{-1}$. In relation to high-productive soils, giant miscanthus showed an increase in this indicator in the fourth to sixth vegetation year - from 16.7 to $23.9 \mathrm{t} \cdot \mathrm{ha}^{-1}$ compared to millet switchgrass, yield of which increased in the third to seventh vegetation years under these conditions - from 14.7 to $19.3 \mathrm{t} \cdot \mathrm{ha}^{-1}$.

In general, under the conditions of the central foreststeppe of Ukraine, the yield of phytomass of energy crops depends on the productivity of each plant regarding the phytocenosis, biometric indicators and growing conditions. The increase in the dry phytomass yield of millet switchgrass, depending on soil conditions of cultivation, is more determined by the number of stems per unit area. Considering the giant miscanthus, it is additionally determined by the plant height. The yield of energy crops in marginal soils depends on the average daily air temperature; the precipitation amount has a less significant effect on this indicator, with the exception of the giant miscanthus.

\section{References}

BAXTER, X. C. - DARVELL, L. I. - JONES, J. M. - BARRACLOUGH, T. YATES, N. E. - SHIELD I. 2014. Miscanthus combustion properties and variations with Miscanthus agronomy. In Fuel, vol. 117, part A, pp. 851-869. doi.org/10.1016/j.fuel.2013.09.003

BEN FRADJ, N. - ROZAKIS, S. - BORZECKA, M. - MATYKA, M. 2020. Miscanthus in the European bio-economy: A network analysis. In Industrial Crops and Products, vol. 148, 112281. doi.org/10.1016/j. indcrop.2020.112281 
ČEDÍK, J. - PEXA, M. - PETERKA, B. - HOLŮBEK, M. - MADER, D. PRAŽAN, R. 2018. Effect of biobutanol-sunflower oil-diesel fuel blends on combustion characteristics of compression ignition engine. In Acta Technologica Agriculturae, vol. 21, no. 4, pp. 130135. doi.org/10.2478/ata-2018-0024

COSTANZA, J. K. - ABT, R. C. - McKERROW, A. J. - COLLAZO, J. A. 2017. Bioenergy production and forest landscape change in the southeastern United States. In GCB Bioenergy, vol. 9, pp. 924-939. doi.org/10.1111/gcbb.12386.

CHRAMIEC-GŁABIK, A. - GRABOWSKA-JOACHIMIAK, A. SLIWINSKA, E. - LEGUTKO, J. - KULA, A. 2012. Cytogenetic analysis of Miscanthus $\times$ giganteus and its parent forms. In Caryologia, vol. 65, no. 3, pp. 234-242.

CHRISTIAN, D. G. - ELBERSEN H. W. 1998. Switchgrass (Panicum virgatum L.). In: BASSAM N. El. Energy Plant Species. Their Use and Impact on Environment and Development. London: James and James Publishers, pp. 257-263. https://www.researchgate.net/ publication/229013519 Switchgrass variety choice in Europe DOSPEHOV, B. A. 1985. Field Experience Technique. USSR, Moscow: Agropromizdat, 336 pp. (In Russian: Metodika polevogo opyita).

KULYK, M. - GALYTSKA, M. - SAMOYLIK, M. - ZHORNYK, I. 2019. Phytoremediation aspects of energy crops use in Ukraine. In Agrology, vol. 1, no. 4, pp. 373-381. http://dspace.pdaa.edu. ua:8080/handle/123456789/4157

KURYLO, V. L. - ROIK, M. V. - HANZHENKO, O. M. 2013. Bioenergy in Ukraine: status and prospects for development. In Bioenerhetyka vol. 1, pp. 5-10. (In Ukrainian: Bioenerhetyka v Ukraini: stan ta perspektyvy rozvytku).

MACÁK, M. - NOZDROVICKÝ, L. - HUSSEIN, A. O. 2015. Effect of preheating and different moisture content of input materials on durability of pellets made from different phytomass content. In Acta Technologica Agriculturae, vol. 18, pp. 22-27.
MATÍAS, J. - CRUZ, V. - GARCÍA, A. - GONZÁLEZ, D. 2019. Evaluation of rice straw yield, fibre composition and collection under mediterranean conditions. In Acta Technologica Agriculturae, vol. 22, pp. 43-47.

MEHMOODA, M. A. - IBRAHIMB, M. - RASHIDC, U. - NAWAZD, M. ALIB, S. - HUSSAINA, A. - GULLE, M. 2017. Biomass production for bioenergy using marginal lands. In Sustainable Production and Consumption. vol. 9, pp. 3-21. doi.org/10.1016/j.spc.2016.08.003

SAMSON, R. - MANI, S. - BODDEY, R. - SOKHANSANJ, S. QUESADA, D. - URQUIAGA, S. 2005. The potential of C4 perennial grasses for developing a global BIOHEAT industry. In Critical Reviews in Plant Sciences, vol. 24, pp. 461-495. doi.org/ $\underline{10.1080 / 07352680500316508}$

TANG, Y. - XIE, J. S. - GENG, S. 2010. Marginal land-based biomass energy production in China. In Journal of Integrative Plant Biology, vol. 52, pp. 112-121. doi.org/10.1111/j.1744-7909.2010.00903.x

THAKRAR, S. K. - GOODKIND, A. L. - TESSUM, C. W. - MARSHALL, J. D. - HILL, J. D. 2018. Life cycle air quality impacts on human health from potential switchgrass production in the United States. In Biomass and Bioenergy, vol. 114, pp. 73-82. doi.org/10.1016/j. biombioe.2017.10.031

TIAN, S. - CACHO, J. F. - YOUSSEF, M. A. - CHESCHEIR, G. M. FISCHER, M. - NETTLES, J. E. - KING, J. S. 2017. Switchgrass growth and pine-switchgrass interactions in established intercropping systems. In GCB Bioenergy, vol. 9, pp. 845-857. doi.org/10.1111/ gcbb.12381

WANG, L. - QIAN, Y. - BRUMMER, J. E. - ZHENG, J. - WILHELM, S. PARTON, W. J. 2015. Simulated biomass, environmental impacts and best management practices for long-term switchgrass systems in a semi-arid region. In Biomass and Bioenergy, vol. 75, pp. 254-266. doi.org/10.1016/j.biombioe.2015.02.029. 